\title{
History and Theory
}

\section{STUDIES IN THE PHILOSOPHY OF HISTORY}

Editor: GEORGE H. NADEL

CONTENTS OF VOLUME II, NO. 1

w. B. GALLIE, The Historical Understanding

VERNON X. DIBBLE, Four Types of Inference from Documents to Events

G. LICHTHEM, Sartre, Marxism, and History

Review Essays:

MARC BLOCH, Feudal Society (L. Walker)

F. SMTTH FUSSNER, The Historical Revolution (George H. Nadel)

LEE BENSON, Turner and Beard (Burleigh Wilkins)

ROBERT SHACKLETON, Moritesquieu (Melvin Richter)

THEODOR SCHIEDER, Begegnungen mit der Geschichte (W. M. Simon)

LOUSS HOROWITZ, Radicalism and the Revolt Against Reasion (A. B. Spitzer)

s. WhlIAM HALPERn, ed., Some 20th-Century Historians (Nelly S. Hoyt)

Subscriptions (\$5.00 U.S. or equivalent, per volume) obtainable from local booksellers and subscription agencies, or directly from:-

MOUTON \& CO, publishers, The Hague, P.O.Box 1132, The Netherlands

\section{$R A C E$}

THE JOURNAL OF THE INSTITUTE OF RACE RELATIONS

\section{Jermyn Street, London S.W.1}

Vol. V, No. 2, October 1963

HENRI TAJFEL, Stereotypes

ANDREW SAARF, Nazi Racialism and British Opinion

o. D. Wollhem, The Coloured People of South Africa

michael banton, African Prophets

R. B. DAVISON, The Distribution of Immigrant Groups in London

PAUL FORDhaM and H. C. WILTShIRE, Some Tests of Prejudice in an East

African Adult College

\section{Subscriptions to:}

\section{OXFORD UNIVERSTTY PRESS}

Amen House, Warwick Square, London E.C. 4

12s.6d. each issue, 40s. a year (in U.S.A. and Canada $\$ 6.00$ ) 


\section{ANNALES}

\section{Economies Sociétés Civilisations}

REVUE BIMESTRIELLE FONDÉE EN 1920

par

\section{LUCIEN FEBVRE \& MARC BLOCH}

Comité de direction:

FERNAND BRAUDEL

GEORGES FRIEDMANN - CHARLES MORAZE

Secrétaire du Comité: PAUL LEUILLIOT

Secrétaire de la Rédaction: MARC FERRO

Au sommaire du $\mathrm{n}^{\circ} 1$ - janvier-février 1964

\section{Etudes}

P. FRANCASTEL Poussin et l'homme historique

E. MATHIAS Idéologie et pratique: le faux débat Bernstein-Kautsky

Mises au point

R. ROMANO Encore la crise de 1619

E. APPOLIS Mystiques portugais au $\mathrm{XVIII}^{\circ}$ siècle

Vie scientifique

P. Leuilliot Au Colloque de Lille: le charbon hier et demain

Histoire et techniques nouvelles

J. BOUviER Comptabilité économique et plan français

\section{Notes critiques}

Peut-on écrire une histoire du fascisme?

E. FASANO, Ouvrages récents sur le fascisme italien

P. AYCOBERRY, Synthèses sur le nazisme

P. VAGO, En Roumanie: note historiographique

P. AKamatsu, Au Japon: l'armée et le prince Konoye

P. NORA, Les deux apogées de l'Action française

J. P. PETER, L'histoire à l'épreuve de la guerre d'Espagne

\section{Comptes rendus}

Aspects de l'économie des états contemporains

Afrique Noire (Première partie)

Rédaction: 20, rue de la Baume, Paris-VIIIe

Administration:

LIBRAIRIE ARMAND COLIN, 103, Bd St. Michel, PARIS-Ve

Compte de chèques postaux: Paris, $\mathrm{N}^{\circ} 1671$

Abonnements: France et Union française, 29 F.; Etranger, 35 F.

Le numéro de 208 pages: $6 \mathrm{~F}$. 


\title{
THE AUSTRALIAN JOURNAL OF POLITICS AND HISTORY
}

\author{
Editor: Gordon Greenwood \\ Issued twice yearly, in May and November
}

VOL. IX, NO. 2

NOVEMBER, 1963

Problems of Australian Foreign Policy January-June 1963

R. G. NEALE

China's Other Boundaries

R. RAHUL

Playford and the Liberal and Country League of South Australia

KATHARINE WEST

Post-Colonial Politics: A Suggested Interpretation

of the Indonesian Experience, 1950-1958 HANS O. SCHMITT

The 1963 Queensland State Election CLAIRE SKERMAN CLARK \& MARGARET N. LETTICE

Australia and the Anglo-Japanese Alliance,

1901-1911

I. H. NISH

The British Empire in the American Rejection of the Treaty of Versailles

N. K. MEANEY

Australian Political Chronicle: Book Reviews

SUBSCRIPTION:

(including postage) Australia $£ 1 / 1 /$ - per year or $12 / 6$ per copy; United Kingdom $f 1$ stg.; U.S.A. and Canada $\$ 2.75$

\section{UNIVERSITY OF QUEENSLAND PRESS}

St. Lucia, Queensland, Australia 


\section{ANTHROPOS}

\section{International Review of Ethnology and Linguistics}

Vol. $56 \quad 1961 \quad$ Fasc. 3-4
O. MORS $\dagger$
H. AUFENANGER
D. DUNSELMAN
J.-P. ROUX
C. LAUFER
A. CLOSS
L. CIPRIANI
H. KELM

A. P. KHATRI

M. GUSINDE

P. ROZING

E. PORÉE-MASPERO
Aus dem Höflichkeitskodex der Bahaya.

The Cordyline Plant in the Central Highlands of New Guinea.

Ngebau tadjau, een cosmogonie der Mualang-Dajaks. Le chaman altaïque d'après les voyageurs européens des XVIIe et XVIIIe siècles.

Gebräuche bei Herstellung einer melanesischen Schlitztrommel.

Die Heiligkeit des Herrschers.

Hygiene and Medical Practices among the Onge (Little Andaman).

Einige Bemerkungen zur Frage der sogenannten $\mathrm{Ku}$ rukwa in Ostbolivien.

Stone Age and Pleistocene Chronology of the Narmada Valley (Central India).

Totemistische Eigentumsmarken der Guajiro-Indianer. Reisaussaat am Ndora-Berg (Flores, Indonesien).

Krŏñ Pãli et rites de la maison.

\section{MICRO-BIBLIOTHECA ANTHROPOS}

A. BuRgmanN Otto Meyers Wörterbuch der Tuna-Sprache auf Neubritannien.

\section{ANALECTA ET ADDITAMENTA}

E. A. WORMS Konferenz zum Studium der australischen Eingeborenen in Canberra, A. C. T., Australien.

H. Aufenanger A Children's Arrow-Thrower in the Central Highlands of New Guinea.

P. Rozing Bedeutung der Maultrommel in Nage-Keo (MittelFlores, Indonesien).

MISCELLANEA - BIBLIOGRAPHIA - PUBLICATIONES RECENTES PERIODICA

Published by: Anthropos-Institut

Editor: P. Arnold Burgmann, S. V. D

POSIEUX (Freiburg), Switzerland 


\title{
CANADIAN JOURNAL OF ECONOMICS
}

\section{AND POLITICAL SCIENCE}

\author{
VOLUME XXX - NUMBER 1 \\ FE B R UAR Y, 1964
}

The Problem of "Minority" Government in Canada

EUGENE FORSEY

Some Liberal Marxists and Left-Wing Catholics in

Contemporary Poland

R. HISCOCKS

The Post-Stalin "Thaw" and Soviet Political Science BOHDAN R. BOcIURKIw Tropical African Contributions to Federal Finance JOHN F. DUE

Size of Firm, Oligopoly, and Research: The Evidence

D. HAMBERG

Short-Term Capital Movements and the Flexible Canadian

Exchange Rate, 1953-1961

I. L. POWRIE

Some Notes on Price Discrimination

STEPHEN ENKE

\section{Notes on Memoranda}

Recent Developments in the Work of the Dominion Bureau of Statistics

MARJORIE TUCKER

An Economic Analysis of the Goldenberg Report

SHEILA EASTMAN

A Note on Seasonal Fluctuations in Canadian

Expenditure

FRANK T. DENTON

Vacation of Seats in the House of Commons:

The Problem of Burnaby-Coquitlam

J. R. MALLORY

Reviews of Books

$\$ 6.00$ per year

$\$ 1.50$ per single issue

UNIVERSITY OF TORONTO PRESS

Front Campus, University of Toronto, Toronto 5, Canada 


\section{Historical Abstracts}

BIBLIOGRAPHY OFTHEWORLD'S PERIODICALLITERATURE BIBLIOGRAPHIE DES PUBLICATIONS PERIODIQUES MONDIALES BIBLIOGRAPHIE DER ZEITSCHRIFTENLITERATUR DER DELT BIBLIOGRAFIA MUNDIALDE PUBLICACIONES PERIODICAS ВИВЛИОГРАФИЯ МИРОВОИ ПЕРИОДИчЕСКОИ ЛИТЕРАТУРЫ

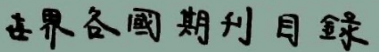

ERIC H. BOEHM, Editor

English summaries of historical articles $(22,563$ to date) on the period 1775-1945 from nearly 2,000 periodicals

Professional and Bibliographical News

Further information or free Index Number on request

HISTORICAL ABSTRACTS

800 EAST MICHELTORENA STREET, SANTA BARBARA, CALIFORNIA, USA

\section{INTER-AMERICAN REVIEW OF BIBLIOGRAPHY}

\section{REVISTA INTERAMERICANA DE BIBLIOGRAFIA}

A quarterly devoted to the study of the Americas with contributions $A$ in English, Spanish, Portuguese and French, published by the Division of Philosophy and Letters (Department of Cultural Affairs) of the Pan American Union, Washington, D. C.

ARMANDO CORREIA PACHECO Editor

JOSÉ E. VARGAS Associate Editor

Articles, Review Articles, Book Reviews, listing of Recent Books, and Notes and News

- Occasional section for bibliophiles

- Separate Annual Index and Table of Contents

All communications should be addressed to the Editor, Room 108, Pan American Union, Washington 6, D.C., U.S.A.

Annual subscription for members of the Postal Union of the Americas and Spain, US $\$ 3.00$; for all other countries, US $\$ 3.50$, to cover mailing costs. Single copies, US $\$ 1.00$. Address the Office of Publications Services, Pan American Union, Washington 6, D. C., U.S. A. 


\section{SUR VEY}

January 1964

A JOURNAL OF SOVIET AND EAST EUROPEAN STUDIES

Our FIFTIETH JUBILEE NUMBER is devoted to three topics:

The Present State of West-East Relations

is discussed by Sir William Hayter, Denis Healey, Louis Halle

and Raymond Aron

Soviet and East European Studies

a critical review from various parts of the globe; reports by Adam Ulam, Alexander Gerschenkren, Victor Frank, Walter Laqueur, Basil Kerblay,

Jens Hacker, and Leopold Labedz.

Sorictology - Pro and Contra

contributions by Alec Neve, Arthur Adams, Peter Wiles, and Harry Rigby.

\section{S U R V E Y}

is published quarterly.

One year's subscription: 30 s. or $\$ 4.00$

Special Student Rates

Our Agents in the United States:

Franklin Square Subscription Agency,

545 Cedar Lane, Teaneck, New Jersey, U.S.A.

Write to:

SURVEY, ILFORD HOLSE, 133 OXFORD STREET, LONDON, W.1.

\section{THE WORLD TODAY}

The monthly review of the Royal Institute of International Affairs provides the general reader with up-to-date and reliable information on current world problems.

Recent numbers include articles on:

South Africa - Behind the Boom

China Irredenta

The North

The South

The Problem Protectorates

Poiand and Khrushchev's Russia

Margaret Roherts

F. C. Jones

W. O. Wolters

Theodore Bull

Margareth Miller

Annual Subscription: $35 \mathrm{~s}$. (U.S.A. and Canada $\$ 5.30$ ) $3 \mathrm{~s}$. per issue

Orders may be sent to booksellers and newsagents, or to the OXFORD UNIVERSITY PRESS, PRESS ROAD, NEASDEN, LONDON N.W. 10 


\section{PANORAMAS \\ REVISTA BIMESTRAL}

Número 7

S UMARIO

Enero-febrero de 1964

POlTtica Y Pédagogia. Juan José Arévalo: La pedagogía como política y la política como pedagogía. Olga Cossettini: La educación popular y los obreros - EL PERU ANTE SU PORVENIR: Jorge Luis Recavarren: De la frustracíon a la acción. Partido Aprista Peruano: Diagnóstico del proceso económico social Andrés Stawar: Burocracia, Nacionalismo y Psicología del poder - PERIodicos NORTEAMERICANOS Y PERIODISTAS RUSOS: $\boldsymbol{W}$. $K$. Mayo: La prensa en los Estados Unidos. Víctor Nekrasov: Notas de un viaje por los Estados Unidos - Albert $O$. Hirschman: Cómo se adoptan las decisiones económicas. Ramón Cancel Negrón: Testimonio de un puertorriqueño en el mundo latinoamericano AGUJA DE MAREAR: El socialismo europeo en transformación - Africa empieza mal - Cómo nos vemos - Homo sapiens - In memoriam - Fichas - Biblioteca - UN MANUAL DE EDUCACION CIVICA: Las ideologías políticas contemporáneas.

Director: Victor Alba

Suscripción anual en América y España: 2 dólares.

Suscripción anual fuera de América: 3 dólares

APARTADO 25468, MEXICO 5, D.F. MEXICO

\section{THE AMERICAN \\ SOCIOLOGICAL REVIEW}

Journal of the American Sociological Association

An authoritative publication devoted to the social sciences

Selects and publishes the best writings in the field.

Reflects new trends and developments in theory and research.

Reports on subjects of current significance.

Reviews the important new books on sociology and related subjects.

Bi-monthly-Subscriptions are included in membership in the ASSOCIATION

$\$ 8.00$ per year Current Volume $28 / 1963$ February through December THE AMERICAN SOCIOLOGICAL ASSOCIATION

SUITE 215

1755 MASSACHUSETTS AVENUE N.W. WASHINGTON D.C. 20036 


\title{
NORTH KOREA
}

North Korea is probably the most unknown country behind the Iron Curtain. Not many Westerners have been there since the outbreak of the Korean War and precious few before that. In an attempt to fill the vast areas of ignorance, The China Quarterly is presenting a special issue on North Korea with articles by a number of academic specialists. The topics include:

\author{
Agricultural Development \\ Industrial Development \\ The Foreign Policy \\ The Educational System \\ The People's Army and the Party \\ The Judicial and Administrative Structure
}

Subscriptions $\$ 4.00$ (students $\$ 3.00$ ) per year

April-June (No. 14) issue of

THE CHINA QUARTERLY

Ifford House, 133 Oxford Street, London, W.1.

\section{JOURNAL OF SOUTHEAST}

\section{ASIAN HISTORY}

Published twice yearly by the Department of History, University of Singapore

EDITOR: K. G. TREGONNIVG

Vol. 4, No. 1. March, 1963

The Origin of the Javanese Mosque

The Coming of Islam to North Sumatra

Historians in Indonesia Today

Peasant and Land Reform in Indonesian Communism

On the Need for a Study of Malaysian Islamization

The Uniqueness of Philippine Nationalism

British and American Influence in Thailand

The "Kim Eng Seng"
H. J. de Graaf

A. H. Hill

Sartono Kartodirdjo

Justus M. van der Kroef

Syed Hussein Alatas

R. S. Milne

Frank C. Darling

Nicholas Tarling

\section{Annual Subscription: $\$$ M $10 /-(£ 1.3 .6)$}

Order from:

The Secretary

History Department, University of Singapore, Singapore 10. 


\section{INTERNATIONAL JOURNAL OF COMPARATIVE SOCIOLOGY}

A Journal devoted to research, especially in the problems of social change arising out urbanization, industrialization and cross-cultural contacts. Eminent sociologists from all over the world are on the Editorial Board.

Editor: K. ISHWARAN

Karnatak University, Dharwar, India.

Vol. IV, No. II.

A Special Number devoted to: Urbanism and Urbanization Guest Editor: NELS ANDERSON

Bonn, West Germany.

I. ARTIÇLES:

1. Introduction

2. Aspects of Urbanism and Urbanization . . Nels Anderson

3. The Rise and Fall of Cities . . . . . . Gideon Sjoberg

4. Changes in Urban - Rural Relationships in Industrial Society . . . . . . . . . Herbert Kötter

5. The Governmental Framework of Urban Planning . . . . . . . . . . . William Robson

6. Urbanization of Southeast Asia . . . . J. D. N. Versluys

7. The Pattern of Urbanization of Australia . Tom Brennan

8. Urbanism, Engineering Trends in Ethiopia . Perry Fellows

9. Urbanization and Social Transformation in India . . . . . . . . . . . . . Ramkrishna Mukherjee

10. The Ideology of Islamic Urbanization . . F. Benet

11. Urbanization in Latin America . . . . . T. Lynn Smith

12. Urban Activity, Urban People and Urban Environment in Scandinavian History . . Börj Hanssen

13. Urbanization and Urbanism in the United States . . . . . . . . . . Joseph Vandiver

II. NOTES AND NEWS:

Notes and News; Book Reviews; Publications Received.

The Journal is published twice a year (March and September) by the Department of Social Anthropology, Karnatak University, Dharwar India. Annual Subscription Rates: $\$ \mathbf{8 . 0 0}$ or equivalent in other currencies

ORDER FROM:

E. J. BRILL - LEIDEN, HOLLAND 


\title{
REVISTA DE ESTUDIOS POLITICOS
}

\author{
Bimestral \\ Director: \\ Carlos OLLERO GOMEZ \\ Secretario: \\ Alejandro MUÑOZ ALONSO \\ SUMARIO DEL. NUMERO 131 \\ (Septiembre-Octubre 1963)
}

ESTUDIOS Y NOTAS:

"Tres conceptos antiguos en el mundo moderno: el trabajo, el tiempo y el ocio". ( $2 a$ parte) por Sebastián DE GRAZIA

"Teoria general del estado de derecho". por Elías DIAz

"El poder ejecutivo en la realidad politica contemporanea", por Cesar ENRIQLE ROMERO

"La constitucion Yugoslava del 7 de Abril de 1963", por Juan FLRRANDo

"La nueva constitucion del reino de marruecos", por A. LAZARo

\section{Tecnocracia y politica}

"Los problemas de la tecnocracia y el papel de los expertos", por Roger GREGOIRE

"Los problemas de la tecnocracia en el mundo moderno y el papel de los expertos: informe sobre Francia", por Georges VEDEL.

"Tecnocracia y el papel de los expertos en el gobierno del reino unido", por J. M. MACKENZIE

"El papel de los expertos en la vida politica de Italia", por F. vito

"El papel de los politicos y de los profesionales civiles en la gestacion de la politica en Israel", por Yehezkel DROR

"Tecnocratas, burocratas y politicos en Holanda", por E. DE VRIES

\section{MUNDO HISPANICO:}

"Contenido de la revoluciọn Hispanoamericana", por Fernando MLrillo

\section{SECCION BIBLIOGRAFICA:}

Recensiones - Noticias de libros - Revista de revistas - Libros recibidos

Bibliografia: "Derecho politico y constitucional", por Stefan GLEJDLRA

\section{Precios de suscripción anual:}

España y Territorios de Soberanía Española . . 175 pesetas

Portugal, Iberoamérica y Filipinas . . . . . 200 "

Otros paises . . . . . . . . . . . . . 225 "

Número suelto . . . . . . . . . . . . 45 "

INSTITUTO DE ESTUDIOS POLITICOS - PL.AZA DE LA MARINA

ESPAÑOLA 8 - MADRID-13 (España) 


\section{PARAGON BOOK GALLERY}

"The Oriental Book Store of America"

140 East 59th Street

New York 22, N.Y.

We specialize exclusively in books

on the

FAR EAST, NEAR EAST \& MIDDLE EAST

More than 25,000 "in print" and "out of print" books on Oriental history, religion, philosophy, literature, linguistics and art in all languages are on our shelves. All librarians, scholars, and collectors are invited to send their wantlists, which will receive our very best attention.

\section{Catalogues Issued Regularly}

We purchase single works and complete libraries on the Orient and always pay full value.

\section{F R E E No obligation Get Acquainted Offer THE RUSSIAN REVIEW}

\section{America's Leading Quarterly on Russia Past en Present}

THE RUSSIAN REVIEIV offers you quarterly a thorough, scholarly appraisal of developments in Russia found nowhere else. In the leading $\mathrm{cm}$ bassies of the free-world-in the libraries of the Universities with top Russian departments, the REVIEW is a fundamental source of reliable interpretation and information concerning Russia past and present. Every important work on Russia is here reviewed-its leading articles are by noted and expert observers of the Russian scene.

Editors and contributors include William Henry Chamberlin, H. H. Fisher, Richard Pipes, Gleb Struve, Dimitri von Mohrenschildt, Bertram Wolfe. Let us send you a current issue now-without obligation.

\section{Mail coupon below}

Send me a FREE copy of THE RUSSIAN REVIEW with further details. Name

\begin{tabular}{lll}
\hline Street & & \\
\hline City & Zone & State \\
\hline
\end{tabular}

Box 146

THE RUSSIAN REVIEW

Hanover, N. H. 


\section{GEN US}

THE REVIEW OF THE

\section{ITALIAN COMMITTEE FOR THE STUDY OF POPULATION PROBLEMS \\ and of the}

ITALIAN SOCIETY OF GENETICS AND EUGENICS

edited under the auspices of the

NATIONAL RESEARCH COUNCIL

EDITOR: CORRADO GINI

Vol. $X 1 X, 1963$

\section{Contents}

Robert E. KUTTNER -- Eugenic Aspects of Preventive Therapy for Mental Retardation.

CORRADO GINI - Di un'applicazione della transvariazione alla tassonomia (La regola del $75 \%$ ).

I. Dai la VAlle e S. SAgigese - I Dauada del Fezzan: Caratteristiche demografiche.

GEORgE A. AgOGiNo - The Paleo-Indian in North America

P. EDUARDO NICOLICCHIA - La situazione demografica di Um-el-Araneb nell'ottobre del 1933.

CORRADO GINI - L'America Latina e i futuri sviluppi della Sociologia.

\section{INTERNATIONAL COMMITIEE FOR THE STUDY OF THE HUMAN-I.IKE HAIRY BIPEDS}

I. T. SANDERSON - Some preliminary Notes on Traditions of Submen in Arctic and Subarctic North America.

C. R. DORION -..- Aparecio por tierras de Izabal.

M. J. JuRcich - Tarma, el Hombre Salvaja de America.

CHARI ES CORDIER - Deux anthropoides inconnus marchant debout au Congo ex-Belge.

I. T. SANDERSON - The Winderwasa or Hairy Primitives of Ancient Europe.

RASSEGNA:

CORRADO GINI - Teoria scientifica della cultura e altri saggi.

Recensioni. Bibliografia.

\section{GENUS}

Accepts scientific articles, papers, notes, and communications written in Italian, English, French. German, and Spanish in the field of the different sciences related to population problems (Demography, Sociology, Economics, General Biology, Genetics, Eugenics, Anthropology, Social Hygiene, Psychology, Geography).

Orders should be addressed to: SEgRETERIA DEL COMITATO ITALIANO PER lo STUDio dei PROBlemi DEl.LA POPOlazione - Via delle Terme di Diocleziano, 10 - ROMA - ITALia.

Lit. 3.600,-

U.S.A. $\$ 6$ 


\section{THE EASTERN ANTHROPOLOGIST}

Published thrice a year by the Ethnographic and Folk-Culture Society (U.P.), c/o The Department of Anthropology, University of Lucknow, Lucknow, India.

The Eastern Anthropologist publishes articles and book reviews on all branches of Anthropology without any restrictions regarding approach or the subject dealt with.

Editor: D. K. Sen. Foreign Editors: C. von Fürer-Haimendorf and David G. Mandelbaum. Assistant Editor: T. N. Madan.

Just Published:

Vol. XVI, No. 2 - May_August, 1963

Levels of Economic Initiative and Ethnic Groups in Pargana Barablum, Surajit Sinha. Comparative Study of the Kinship Systems of two Polyandrous Communities, B. Mukherjee. Kinship, Marriage and Family among the Korwa of Dudhi (Mirzapur, U. P.), J. S. Bhandari. The Vienna School of Ethnology, Some Recent Perspectives, Eugen Lupri. Distribution of Middle Phalangeal Hair among Chowra and Terressa Islanders, Pranab Ganguly \& Anadi Pal. Middle-Phalangeal Hair among the Saoras of Puri, Orissa, K. C. Tripathy. Microliths from Nagarjunakonda Valley, P. C. Dutta. A Short Note on the Pedigree of Webbed Toe, H. N. Agarwal. A Note on the Weekly Market at Gokulpeth (Nagpur). Book Reviews.

Annual Subscription: $£ 1 / 10, \$ 5.00$ or Rs 15.00 .

\section{SAECULUM}

\section{Jahrbuch für Universalgeschichte}

From the numbers of the last volume XIII (1962):

Wolfgang Haberland: Zur Geschichte der ackerbauenden Kulturen in Mexiko und Mittelamerika

Pedro Bosch-Gimpera: Die ersten Wellen der Bevölkerung Amerikas

Hans Steiningen: Der Buddhismus in der chinesischen Geschichte

Marie Helmer: Edelmetalle Perus in der Kolonialzeit

E. E. G. Vermeulen: Was ist Objektivität?

Helmut Petri: Zahlungsmittel bei schriftlosen Völkern

Ibarro Grasso: Synthese des Geschichtsverlaufs von den paläolithischen Zeiten bis zur Ankunft der Spanier im südlichen mittleren Andengebiet

Aziz Ahmad: Sufismus und Hindumystik

Kennosuke Ezawa: Japan und die Weltzivilisation

SAECULUM appears four times a year

Annual subscription: DM 34,-

VERLAG KARL ALBER

FREIBURG/MÜNCHEN, GERMANY 


\section{MINERVA}

A REVIEW OF SCIENCE, LEARNING AND POLICY

Vol. I, No. 4

Editor: EDWARD SHILS

Summer 1963

\section{ARTICLES}

The Proper Public of Science:

Reflections on a Cartesian Theme concerning Humanity and the State as Audience of the Scientific Community

D. Dubarle, O.P.

Scientific Cooperation in Western Europe

Pierre Auger

Asian and African Students in the West German University

Prodosh Aich

Central Scientific Organisation in the United States Government A. Hunter Dupree

\section{REPORTS AND DOCUMENTS}

Scientific and Technical Research in France.

Fourth Plan 1962-1965

Report of the Fulton Commission 1963.

Commission to advise on the Creation of a Federal-Type Chines University in Hong Kong

Report of the Indian Vice-Chancellors' Conference, 1962

\section{CHRONICLE}

$*$

Subscription for one year $£ 1.0 .0$ or $\$ 3.50$. Single copies $5 \mathrm{~s}$. Od. Payable to:

\section{MINERVA}

Ilford House, 135 Oxford St., London W.1. 


\section{ECOLE PRATIQUE DES HAUTES ETUDES - SORBONNE}

Sixième Section: Sciences Economiques et Sociales

Division des Aires Culturelles

Centre d'Etudes sur l'U.R.S.S. et les Pays Slaves

\section{CAHIERS DU MONDE RUSSE ET SOVIETIQUE}

Paraît quatre fois par an

Comité de Rédaction

Jacques Bellon. Alexandre Bennigsen, H. Carrere d'Encausse.

Henri Chambre, René David, Claude Frioux, Basile Kerblay, Paul Lemerle, François de Liencourt, Roger Portal.

Secrétaire de Rédaction:

Marc Ferro

AU SOMMAIRE DU VOLUME IV -3

Etudes:

H. zamoiska, Leonid Andreev et le mal du Siècle

J. L. VAN Regemorter, Commerce et Politique: le traité franco-russe de 1787

\section{Documents:}

Un Document inédit sur la campagne de Russie de 1812, Présentation et notes de Ch. QUELQUEJAY-LEMERCIER

Le Dossier "TROTSKI" à la Préfecture de Police de Paris, Annoté et Présenté par Annie KRIEGEL

\section{Chrónique:}

B. Kerblay, Les Propositions de Liberman pour un projet de réforme de l'entreprise en U.R.R.S.

\section{Bibliographie:}

M. LeSURe, Aperçu sur les fonds russes des Archives du Quai d'Orsay

Abonnements: France : 33 F. - Le $\mathrm{n}^{\circ}: 9 \mathrm{~F}$.

Editions Mouton, 45, rue de Lille, Paris $\left(\mathrm{VII}^{\circ}\right)$ - CCP : 50.6796

Etranger : $30 \mathrm{Fl}$. Le $\mathrm{n}^{\circ}: 8 \mathrm{Fl}$.

Ed. Mouton \& Co, P.O.Box 1132, La Haye, Hollande

Rédaction-Administration:

20, rue de la Baume - PARIS - VIIIe 
An International Quarterly

EDITORIAL COMMITTEE

L. A. Fallers

G. E. von Grunebaum

Everett C. Hughes

EdWARd SHILS

ERIC R. WOLF

FREDERICK WYATT

Sylvia L. Thrupp (Editor)
Anthropology

Islamic Studies

Sociology

Sociology

Anthropology

Psychology

Economic History
Chicago

California

Brandeis

Chicago

Michigan

Michigan

Michigan

CONSULTING EDITORS

E. Balazs

JACQUES BARZUN

REINHARD BENDIX

Peter Charanis

Carlo Ctpolla

\section{Willson COATES}

Thomas Cochran

RAYMOND FIRTH

WILLY HARTNER

Grorge C. Homans

Charles W. Jones

George Kubler

Claude Lévi-Strauss

Arnaldo Momigliano

Lucian Pye

Alf Ross

JOSEPH J. SPENGLER

JOSEPH R. STRAYER

Sol TAX

Charles Verlinden

Phitippe WolfF

Christopher Wrigley
Far Eastern Civilizations

History

Sociology

Byzantine Studies

Economic History

History

History

Anthropology

History of Science

Sociology

Comparative Literature

Art History

Anthropology

History

Political Science

Law

Economics

History

Anthropology

Economic History

History

History
Paris

Columbia

California

Rutgers

Turin and

California

Rochester

Pennsylvania

London

Frankfurt

Harvard

California

Yale

Paris

London

Mass. Inst. of

Technology,

Cambridge

Copenhagen

Duke

Princeton

Chicago

Ghent

Toulouse

Ibadan 


\section{Publications of the \\ Institute of Social Studies The Hague}

\section{SERIES MAIOR}

I. S. N. Eisenstadt: Essays on Sociological Aspects of Political and Economic Development. 1961. 88 pp. . . . . . . . f 10,-

II. C. A. O. van Nieuwenhuijze: Society as Process. Essays in Social Sciences Method. 1962. 281 pp. Cloth. . . . . . f 28,-

III. J. A. Ponsioen (ed.): Social Welfare Policy. First Collection: Contributions to Theory. 1962.287 pp. Cloth. . . . . . f 25,-

IV. J. A. Ponsioen: The Analysis of Social Change Reconsidered. A Sociological Study. 1962. 170 pp. Cloth. . . . . . f 14,-

V. C. A. O. van Nieuwenhuijze: Cross-Cultural Studies. 1963. 289 pp. Cloth. . . . . . . . . . . . f 28,

VI. George Kurian: The Indian Family in Transition. A Case Study of Kerala Syrian Christians. 1961. 147 pp., map. . . . . f 15,-

VII. Marion W. Forrester: Kenya To-Day. Social Prerequisites for Economic Development. 1952, 179 pp., 2 maps. Cloth . . . f 15,-

VIII. L. J. Zimmerman (ed.): Economic Planning. ab. 180 pp. Cloth.

In preparation.

IX. J. A. Ponsioen (ed.): Social Welfare Policy. Second Collection: Contributions to Methodology. 1963. $178 \mathrm{pp}$. Cloth . . f 20,-

X. Egbert de Vries (ed.): Essays on Unbalanced Growth. A Century of Disparity and Convergence. 1962. 221 pp. Cloth. . . f 24, -

XI. C. A. O. van Nieuwenhuijze (ed.): Markets and Marketing as Factors of Development in the Mediterranean Basin. Papers presented at the Second Assembly of the Mediterranean Social Sciences Research Council held at Cairo, December 1-4, 1962. With a Summary of the Discussions by D. G. Tsaoussis. 1963. 153 pp. Cloth. .. . . . . . . . . . . . f 16,

XII. Peter C. W. Gutkind: The Royal Capital of Buganda. A Study of Internal Conflict and External Ambiguity. With a Foreword by A. I. Richards. 1963, 350 pp., 9 plates, 7 maps. Cloth. . f 42,- 